\title{
PREFERENCE LECTURERS AND STAFFS IN CONDUCTING SELF MEDICATION
}

\author{
Trini Handayani \\ Postgraduate Lecturer in Law, Suryakancana University \\ Email: trinihandayani@unsur.ac.id
}

\begin{abstract}
Self-medication is one of the medication method in which it can cure the disease of a person in the absence of the need to expend much money and effort as well to visit a practitioner. Self-medication is literally a treatment that is performed by a person him/ herself. An individual can actually purchase an Over the Counter medicine to treat their own disease. If it is done properly, self-medication can bring a huge advantage to the individual him/herself as they need, a medication state in which a person uses more than two medicines all at once. The focus of this research is to comprehend the behaviour of selfmedication among the lecturers and staffs that are located in Suryakancana University. In order to conceive the behaviour of the respondents, a direct interview method is used by interviewing some of them. The interview result indicates that $96 \%$ respondents have performed self-medication at least once. In addition, there are several respondents admit that they have also performed polypharmacy. This also shows that the awareness regarding the correct type of medicine and the understanding of the indication written on the medicine is still relatively low among the lecturers and staffs.
\end{abstract}

Keywords: lecturers, self-medication, staffs, and treatment.

\section{INTRODUCTION}

Health development is an effort carried out by all components of the Indonesian Nation which aims to increase awareness, willingness and ability to live healthy for everyone in order to realize the optimal degree of public health, as an investment for the development of socially and economically productive human resources. The success of the development of the health sector is largely determined by the continuity between program and sector efforts, as well as continuity with the efforts that have been carried out by the previous period. Law Number 25 of 2004 concerning the National Development Planning System (SPPN) mandates that each ministry needs to develop a Strategic Plan (Renstra) that refers to the National Medium Term Development Plan (RPJMN). With the stipulation of the 2015-2019 RPJMN Ministry of Health of the Republic of Indonesia and the Ministry of Health's Strategic Plan for 2015-2019, the Ministry of Health compiled the 2015-2019 Strategic Plan. The Ministry of Health Strategic Plan is an indicative planning document containing health development programs that will be implemented by the Ministry of Health and become a reference in the preparation of annual planning. The Ministry of Health's Strategic Plan was formulated through approaches: technocratic, political, participatory, top-down, and bottom-up. Health development in the 2015-2019 period is the Healthy Indonesia Program with the aim of improving the health status and nutritional status of the community through efforts to health and community empowerment supported by financial protection and health service distribution. The main objectives of the 2015-2019 RPJMN are: 
(1) improved health and nutrition status of mothers and children; (2) increased disease control; (3) increasing access and quality of basic health services and referrals, especially in remote, disadvantaged and border areas; (4) increased coverage of universal health services through the Indonesia Healthy Card and the quality of the management of the National Social Security System (SJSN), (5) the fulfillment of the needs of health personnel, drugs and vaccines; and (6) increasing health system responsiveness.

In accordance with the 2015-2019 Ministry of Health Strategic Plan, there are two health development goals. The first Health Development Goal is an increase in public health status, which is characterized by conditions in 2019 namely the decline in maternal mortality to 306 per 100,000 births; decreasing infant mortality to 24 per 1,000 live births; and the decrease in LBW to 8 percent. The second objective is to increase the responsiveness and protection of the public towards social and financial risks in the health sector, which is characterized by the condition in 2019 of decreasing the burden on households to finance health services after having $10 \%$ health insurance and increasing responsiveness to health services.

The concept of the Human Development Index (HDI) was first published by the United Nation Development Program (UNDP) through the Human Development Report in 1996, which then continues every year. The definition of HDI is a process of enlarging the people's choices. The most important aspect of life is seen from its long age and healthy life, adequate level of education, and a decent standard of living. Specifically, UNDP establishes 4 (four) main elements in human development, namely productivity, equity, sustainability, and empowerment.

The Human Development Index (HDI) in Indonesia, in 2015, amounted to 0.689 , Indonesia was ranked 113 out of 118 countries. While the HDI in West Java Province in 2015 amounted to 69.50, an increase of 0.7 points compared to West Java HDI in 2014 of 68.80 . The basic dimensions that make up the HDI are, the Health Index which is assessed from Life Expectancy (AHH) or a long and healthy life, Education Index or knowledge, and the Buy Power Index in the form of a decent standard of living. Health Index is calculated based on Infant Mortality Rate, under five Mortality Rate, Maternal Mortality Rate and Rough Mortality Rate. The Education Index is based on the Average School Duration and Old School Expectations. Average School Duration (RLS) is the length of time (years) of the population aged 25 years and over in undergoing formal education. School Length Expectation (HLS) is defined as the length (years) of formal schooling expected by children at a certain age in the future.

A decent standard of living is described by per capita expenditure, which is determined by the value of expenditure per capita and purchasing power parity. HDI is calculated based on the geometric average of the health index, knowledge index, and expenditure index. The calculation of these three indices is done by standardizing the minimum and maximum values of each index component. One important aspect of life is health, health is a reflection of the high and low standards of living a person has. Activities carried out by individuals daily depend on health conditions. The way a person gets healthy status is by doing activities that are considered to be healthy. If individuals experience health problems, they can cause illness so that they can interfere with their activities and these individuals will try to recover in various ways, one of which is to consume drugs, both traditional medicine and chemical drugs which are carried out based on insufficient knowledge. In addition, there are those who go to the doctor, or other health workers. Most individuals do self-medication by buying 
medicines from stalls around their homes or intentionally buying from a pharmacy for supplies of medicines at home if a family member falls ill.

Based on the definition cited from Brata et.all, that: Self-medication is defined as "the use of drugs to treat self-disorders or symptoms, or the use of prescribed drugs or symptoms" in another word "drug use without supervision of a physician".

Treatment is an individual's behavior by consuming certain drugs to reduce minor illness symptoms without medical intervention/advice. Self-medication in this case is limited only to modern drugs, namely over-the-counter drugs and limited over-thecounter drugs. The benefits of self-medication using over-the-counter drugs and limited over-the-counter drugs include: safe when used according to the rules, effective in eliminating complaints (because $80 \%$ of complaints are selflimiting or self-cured), cost efficiency, time efficiency, can take part in taking therapeutic decisions, and ease the burden of the government in the limited number of personnel and health facilities in the community.

According to the provisions of Law No.7 of 1963 concerning Pharmacy, chemical drugs are classified into 5 (five) categories. The five categories, if sorted from the most loose to the most strict regarding the rules of security, use, and distribution are as follows: 1) Free drugs; 2) Limited Free Medication (List W or "Waarschuwing", alert); 3) Hard drugs (Register G or "Gevaarlijk", dangerous); 4) Psychotropic Drugs (OCT, Limited Hard Drugs); 5) Narcotics drugs (Register O or "Opium").

Based on drug acquisition, the drug is classified into 2 (two) categories, namely drugs obtained without a doctor's prescription (Over the Counter $=$ OTC) and the medicine obtained must be prescribed by a doctor (Ethical). OTC drugs consist of over-the-counter drugs and limited over-the-counter drugs. Free drugs are indicated by the presence of a green logo with a black edge that is listed in each pack of medicine, this drug can be purchased at stalls, drug stores or pharmacies. While limited over-the-counter drugs are drugs with a black blue edge logo and can be purchased at licensed drug stores and pharmacies. Examples of over-the-counter drugs with a green logo with black edges are: paracetamol (medicine to reduce heat and anti-pain), vitamins (to increase endurance), Bintang Tujuh headache medicine, black cough medicine, white cough medicine, oil eucalyptus, and so on. Whereas limited over-the-counter drugs are marked with a blue black border logo, or commonly referred to as a list of $\mathrm{W}$ drugs (Waarschuwing $=$ alert), for example cough, cold and hot drugs in one package, external drugs such as povidone iodine, and so on.

Medicines obtained by prescription are called ethical drugs; ethical drugs cannot be obtained without a doctor's prescription and are only sold at pharmacies. Ethical medicine has a red logo with black edges and a letter $\mathrm{k}$ in it. Including ethical drugs are hard drugs list G (Gevaarlijk = dangerous), Psychotropic drugs (Limited Hard Drugs = OKT), Narcotics Drugs (List O = Opium) and Compulsory Drug Pharmacies (OWA). OWA is a drug that has the $\mathrm{K}$ logo but may be given without a prescription, given by the pharmacist. Compulsory drug pharmacies have 3 groups, namely groups 1,2 and 3 based on the Decree of the Minister of Health Number 347 of 1990 regulating class 1 compulsory dispensary drugs, Decree of the Minister of Health Number 924 of 1993 , This decree contains additions of mandatory class 2 and final pharmacies. The Decree of the Minister of Health Number 1176 of 1999, contains additional compulsory class 3 pharmacy drugs.

The government has several considerations regarding regulations that contain several mandatory drug pharmacies. Moreover, this regulation also through renewal with the 
increasing list of drugs. However, these considerations are also applied in accordance with the socio-cultural conditions of the community about the importance of knowledge of the drugs to be consumed. Some government considerations that are supported by the minister of health regulations such as:

1. The government considers that the decision on mandatory drug pharmacies will provide convenience to the public to reach the drugs needed without a doctor's prescription. In addition, the government also wants all levels of society to have the ability to have better knowledge when dealing with problems through self-medication safely, appropriately and very rationally. In fact, the government also supports this regulation to provide easy reach through the prices of all drugs available at pharmacies. Knowledge of this price will make it easier for the community to control healthy living;

2. The decision of the health minister will also increase the role of pharmacists in pharmacies to maximize services to people who need drugs. In fact, pharmacists are also considered necessary to provide education on the use and function of good drugs in accordance with the required dose. Pharmacists can also be counselors for all types of drugs needed by the community. Pharmacists are required to provide information that is correct and appropriate to the function, dosage and price of drugs given directly to the community;

3. Through this decision, the government wants the entire supply of drugs in pharmacies to increase to provide convenience to the public. However, the supply of medicines at the pharmacy will also go through a control process that has also been determined by the ministry of health. So that the number of drugs that can be reached by the public has a good and not too excessive impact.

Figure 1 Drug Characteristics

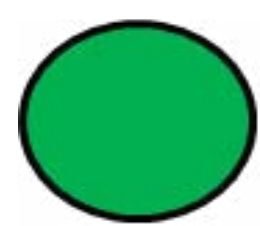

FREE MEDICINE ON SALE: IN THE MARKET LICENSED DRUG STORE PHARMACY

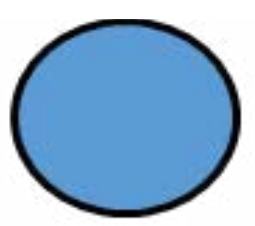

FREE MEDICINE LIMITED LICENSED DRUG STORE PHARMACY

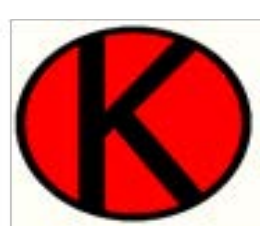

HARD DRUG PHARMACY

Free drugs and over-the-counter drugs are limited if used properly, greatly helping the community in self-medication safely and effectively. People do self-medication often not in accordance with the rules of use, sometimes people consume drugs that are actually not needed, or even can be dangerous. However, over-the-counter drugs and limited over-the-counter drugs do not mean free of side effects so that the user must also be in accordance with the indications, the correct duration of use, accompanied by user knowledge about the risk of side effects and their contraindications. The use of over-thecounter drugs and limited over-the-counter drugs that are in accordance with the rules and conditions of the patient will support efforts to use rational drugs. The rationality of drug use consists of several aspects, including: the accuracy of the indication, the suitability of the dose, the presence or absence of contraindications, the presence or 
absence of side effects and interactions with drugs and food, the presence or absence of polypharmacy (use of more than two drugs for the same disease indication). ${ }^{1}$

Knowledge of self-medication is generally still low and public awareness to read labels on drug packaging is still small. The main source of information for self-medication generally comes from the mass media. Information from drug manufacturers, there are those that lack educating the public, some are even less correct. Until now the most influential factor in the behavior of self-medication is unknown. However, based on the results of Bello's research, according to sociodemographic factors such as age, gender, and income, the most self-medication groups were under 30 years old (59.5\%), female sex $(61.9 \%)$ and high income group $(40.5 \%) .^{2}$

Study conducted by Thang ${ }^{3}$ states that the behavior of geriatric patients in doing their own treatment shows that the number of patients who do not have health insurance more self-medication compared to patients who have health insurance means the results of the analysis show that the ownership of health insurance has a significant relationship with treatment behavior. Fang, Yang, Feng, Ni, and Zhang ${ }^{4}$ have conducted a study of people's behavior to get health services stating that attitudes have a significant relationship with treating behavior. Knowledge of respondents did not have a significant relationship between individual knowledge and treat behavior. Education does not have a significant relationship with treating behavior. Income does not have a significant relationship with treating behavior. There is a relationship between health insurance and treating behavior.

Based on the background of the problem above, the problems that will be discussed in this research are how the community behaves in doing self-medication. The purpose of this study is to find out and analyze the behavior of the community in conducting selfmedication, especially the behavior of lecturers and education staff in Suryakancana University.

The method used in this article is mixed method. First, quantitative research is carried out and then analyzed qualitatively. The research respondents were lecturers and education staff in Suryakancana University. The research location was chosen in Cianjur Regency, which is located in West Java Province, because it is a district that has almost all the villages and is relatively close to the Special Capital Region of Jakarta. Cianjur Regency has a ratio of the number of pharmacies per small population, so it is suspected that many stalls sell drugs. The number of pharmacies in Cianjur Regency is 117 pharmacies. The total population is $2,624,279$ people, consisting of $1,395,845$ men (53\%) and 1,228,434 women (47\%) in 2014 (Profile of Kabupaten Cianjur). The ratio of pharmacies to the population in Cianjur Regency is 1: 22,000, which indicates that the number of pharmacies in Cianjur Regency is inadequate. Whereas according to the Ministry of Health the ideal ratio of pharmacies to the total population is $1: 10,000$. There are 216 general practitioners, 45 specialists (data from the Indonesian Medical Association Cianjur Branch in 2017). The material and sources of data in this study are

\footnotetext{
${ }^{1}$ HS. Krishnan and M. Schaefer, Evaluation of the impact of pharmacist's advice giving on the outcomes of self-medication in patients suffering from dyspepsia, Pharmacy World Science, Volume 22, Number 3, September 2010, page $102-8$.

${ }^{2}$ SI Bello and IK Bello, Community pharmacist impacts on self-medication management among rural dwellers, Kwara state central, Nigeria, International Journal Research Development Pharmacy Law Science, Volume 2, Number 5, May 2013, page 611-9.

${ }^{3}$ Thang, DX., 2013, An investigation of non-prescription medicine supply in community pharmacies in Hanoi Vietnam, PhD Thesis, University of Nottingham, Nottingham UK.

${ }^{4}$ Yin Fang and K Zhang, Pharmacists' perception of pharmaceutical care in community pharmacy: a questionnaire survey in Northwest China, Health Social Care Community, Volume 19, Number 2, December 2011, page 189-97.
} 
questionnaires. Before making a measuring instrument a questionnaire, Focus Group Discussion (FGD) was conducted on a group of people outside the research respondents to explore more information about self-medication that had been done by the community. Only 1 (one) respondent claimed to have never carried out self-medication among 20 respondents who carried out preliminary interviews before taking to the field to carry out the research. Data collection is done by using a questionnaire measuring instrument that was developed by the researcher. The questionnaire consisted of several groups of questions, namely the identity of the respondent, the behavior of self-medication, related to the right medicine, the right dose, the presence of side effects of drugs or allergies, and polypharmacy. The study was conducted by dividing a questionnaire containing the identity of the respondent and questions related to self-medication. Samples taken were 71 (seventy one) people. Respondents consisted of lecturers and education staff in Suryakancana University. The inclusion criteria in determining the sample are respondents not health workers, not illiterate, self-medication for complaints of the disease, and using drugs from stalls/drug stores or pharmacies. After completing the research, respondents were given enlightenment about correct and correct selfmedication so that this respondent expected that the change in self-medication behavior would be less appropriate.

\section{DISCUSSION}

\section{Research Result}

Respondents studied were lecturers and education staff who worked in Suryakancana University. Samples are taken because respondents are educated people. It will be easier to direct and provide understanding to the respondents. It is hoped that after gaining an understanding of correct and correct self-medication, it will channel this knowledge to the people in the Cianjur environment.

According to Article 1 of the Republic of Indonesia Presidential Regulation Number 10 of 2016 concerning Lecturers and Education Personnel at New State Universities number 4, Lecturers are professional educators and scientists with the main task of transforming, developing and disseminating Science and Technology through Education, Research and Service to the community, then in number 5 is written, Education Personnel are members of the community who are devoted and appointed to support the implementation of education. In order to carry out tasks both as lecturers and as educational staff, competencies are needed which are intelligent actions and responsibilities which are requirements for an ability to carry out tasks in certain areas of expertise. In addition, lecturers and education staff are considered qualified in helping to solve problems in the community and gain more trust than other community groups, including issues about overcoming health problems through self-medication. ${ }^{5}$

The results of the 71 respondents indicated that 68 respondents had self-medication and the remaining 3 respondents had never done self-medication.

Table 1. Distribution of Characteristics of Respondents in Cianjur Regency

\begin{tabular}{ccc}
\hline Variable & Amount & Percent (\%) \\
\hline
\end{tabular}

\section{Gender}

$\begin{array}{lll}\text { - Female } & 39 & 55 \\ \text { - Male } & 32 & 45\end{array}$

${ }^{5}$ Peraturan Presiden Republik Indonesia Nomor 10 Tahun 2016 tentang Dosen Dan Tenaga Kependidikan Pada Perguruan Tinggi Negeri Baru. 
Age

$<30$ Year

$\geq 30$ Year

Level of education

- High (graduated from college) 46

- Low (SD/SMP/SMA) 25

Job Status

- Work

- Does not work

0

0

\section{House Location}

- Rural

- Urban

From Table 1, it can be seen that most of the respondents are female, that is equal to $55 \%$, most of the respondents are under 30 years old, that is $80 \%$, most of the respondents are highly educated (graduated from Higher Education) 80\% and 100\% of respondents work both as a lecturer and as an education staff and the location of his house are mostly in urban areas, which is $72 \%$ considering the location of Suryakancana University in downtown Cianjur.

Table 2. Distribution of Self-Medication Behavior in Cianjur Regency

\begin{tabular}{llcc}
\hline \multicolumn{1}{c}{ Variable } & Category & Amount & Percent (\%) \\
\hline Self-Medication & Ever & 68 & 96 \\
& Never & 3 & 4 \\
Accuracy of medicine & Ever & 61 & 90 \\
& Never & 7 & 10 \\
\multirow{2}{*}{ Accuracy of Dosage } & Ever & 46 & 68 \\
& Never & 22 & 32 \\
Polypharmacy & Ya & 3 & 4 \\
& No & 65 & 96 \\
\hline
\end{tabular}

From Table 2, it can be seen that the majority of respondents had self-medication, which amounted to $96 \%$, most of the respondents answered that the drugs consumed were correct, which amounted to $90 \%$, while for the accuracy of the dose, the percentage was smaller, at $68 \%$ and at why the question is not appropriate dose, the average respondent answers, because the drugs consumed are normal, so the respondent does not need to read the rules of use listed on each drug package. There are still respondents, $4 \%$ claim to do polypharmacy, meaning that respondents consume drugs more than one type with the same efficacy. After further questioning, the average respondent's answer was because it did not work with the initial medication after a few minutes, then continued with the second drug with the same efficacy.

The results obtained were immediately informed to the respondent while providing an understanding of proper self-medication so that the safety of the treatment could be maintained properly. After lecturers and education staff are exposed about understanding 
the right self-medication, it is expected to be able to pass on the understanding of selfmedication to friends on campus, to families in the home and surrounding communities as well as local stall owners who sell certain drugs.

Leenen argues that legislation specifically applied in health services has a theoretical basis and is the basis of health law concerning the right to health services and human rights to determine their own destiny. ${ }^{6}$

\section{Self-Medication Behavior}

Behavior theory explains that recommendations from people who are important or influential in a person's life will influence someone to take an action called subjective norms on the Theory Planned Behavior concept and enabling factors on the concept of Precede Model. In the findings of this study, these concepts can be used to help explain why marital status is related to treatment seeking behavior, namely that advice from a husband or wife can be a strong driver for someone deciding to choose a treatment search effort, for example whether it self-care or referral/consultation efforts to other parties. $^{7}$ Lecturers and education staff can be called important and influential people, both on campus, family or surrounding communities. An understanding of proper self-medication by lecturers and education staff will be able to influence and invite the surrounding community to comply with what they have been exemplified, one of which is about proper self-medication.

In many cases of illness, self-medication is the first choice that makes behavior selfmedication common in the world. Self-medication is expected to reduce the burden of medical services, reduce the time needed to meet doctors, and save costs, especially in economically disadvantaged countries with limited health resources. It does not mean that responsible self-medication is free from risks that can increase the burden and costs that are beyond the ability of self-administered actors because they can cause adverse side effects and require medical intervention.

Several studies on self-medication revealed that the use of doses that were lacking (subdosis), and the frequent use of antibiotics in patients with hot symptoms and using drugs that were initially obtained by prescription, were purchased and consumed in the future if there were similar or similar complaints. A study was carried out in the Khartoum region of Sudan, self-medication by the people in the area was high and selfmedication using $73 \%$ of the people in the Khartoum region, Sudan. ${ }^{8}$

Self-medication is useful in the treatment of minor ailments when done correctly and rationally. The benefits of self-medication are safe when used in accordance with instructions (side effects can be estimated), effective in eliminating complaints because $80 \%$ of illnesses are self-limiting, ie self-healing without the intervention of health workers, cost of purchasing drugs is relatively cheaper than health care time because there is no need to visit health facilities / professions, feel there is their own satisfaction because they take an active role in therapeutic decision making, participate in the health care system, avoid shame or stress if they have to show certain body parts in front of health workers, and help the government overcome the limited number of health workers in the community. The lack of self-medication is that the drug can endanger health if it is not used according to the rules, waste of time and money when using drugs, there is a

\footnotetext{
${ }^{6}$ F. Tengker, 2010, Hukum Kesehatan Kini dan Disini, Mandar Maju, Bandung, page 14.

${ }^{7}$ Aris Widayati, Health Seeking Behavior di Kalangan Masyarakat Urban Di Kota Yogyakarta, Jurnal Farmasi Sains Dan Komunitas, Volume 9, Nomor 2, November 2012, page 64.

${ }^{8}$ NM. Agabna, Self-medication, Sudan Journal of Rational Use of Medicine, Volume 5, Nomor 6, June 2014 , page 4 .
} 
small chance of unwanted drug reactions, such as sensitivity, side effects or resistance, wrong drug use due to information incomplete from drug advertisements, ineffective due to misdiagnosis and drug selection, and difficult to act objectively because drug selection is influenced by past drug use experiences and social environment. ${ }^{9}$

Source of medication in Indonesia according to Herman and Susyanty ${ }^{10}$, includes 3 (three) interconnected sectors, namely household medicine/self-medication, traditional medicine, and professional medical treatment. In the treatment of pain, one can choose one to five sources of medication, but the first action that is most often done is selfmedication. The criteria used to choose the source of medication according to Smith ${ }^{11}$ are knowledge about illness and its treatment, belief in medication/treatment, severity of illness, affordability, and distance to the source of treatment. Of the 4 (four) criteria, the severity of illness is the dominant factor. The decision-making process to choose the source of treatment begins with receiving information, processing various possibilities and impacts, followed by making decisions from various alternatives. A person's interpretation of pain can be different so that it influences the decisions taken. For example, lethargy when you wake up can be interpreted as fatigue by people who are working hard, flu symptoms in cloudy weather, or getting sick more severe by people with chronic diseases. Different interpretations of pain can lead to the selection of different treatment sources. In an effort to overcome childhood diseases, generally residents in rural areas of Central Java choose self-medication for mild severity of illness, treatment with paramedics or medical at moderate severity, and treatment with traditional healers at severe severity.

In accordance with Minister of Health Regulation No.919/MENKES/PER/X/1993, the criteria for drugs that can be delivered without prescription or drugs that are safe for self-medication are: (1) Not contraindicated for use in pregnant women, children under 2 years of age and people over 65 years old; (2) Self-medication with the intended drug does not pose a risk to the continuation of the disease (need to be careful in reading drug packaging); (3) Its use does not require special methods or tools that must be performed by health workers or need to monitor health personnel, such as nebulisation devices for patients with shortness of breath complaints; (4) Its use is needed for diseases of high prevalence in Indonesia, such as diarrhea, Acute Respiratory Tract Infection (ARI); and (5) The intended drug has a safety efficacy ratio that can be accounted for for selfmedication. ${ }^{12}$

Someone does self-medication because it is based on his experience or family, uses the rest of someone else's medicine, and uses a coppy recipe. While the factors that encourage self-medication are the development of innovative pharmaceutical technology, types or brands of drugs in circulation that are widely known or known to the public, public awareness of the importance of health, influence of information or advertising, ease of obtaining drugs, and high health costs.

The types of drugs that can be used in self-medication, namely:

a. Medicines that are obtained without a doctor's prescription/drug Over The Counter (OTC), consisting of over-the-counter drugs and limited over-the-counter drugs;

\footnotetext{
${ }^{9}$ Supardi Sudibyo dan Mulyono Notosiswoyo, Pengobatan Sendiri Sakit Kepala, Demam, Batuk Dan Pilek Pada Masyarakat Di Desa Ciwalen, Kecamatan Warungkondang, Kabupaten Cianjur, Jawa Barat, Majalah Ilmu Kefarmasian, Volume II, Nomor 3, September 2016, page 136.

${ }^{10}$ MJ Herman and AL Susyanty, An analysis of pharmacy services by pharmacist in community pharmacy, Buletin Penelitian Sistem Kesehatan, Volume 15, Number 3, March 2012, page 271-81.

${ }^{11}$ Ferdinand Smith, Community pharmacy in Ghana: enhancing the contribution to primary health care, Health Policy Planning, Volume 19, Number 4, April 2004, page 234-41.

${ }_{12}$ Peraturan Menteri Kesehatan Nomor 919/ Menkes/ Per/ X/1993.
} 
b. Obligatory Drug Pharmacy (OWA) is a hard drug without a doctor's prescription, even though the sign: dark circles, red base, can be given by the pharmacist without going through a doctor's prescription. Examples of OWA are family planning pills, gastrointestinal drugs, worm medications and ointments, both antibiotic ointments and hypo-allergenic ointments;

c. Food or vitamin supplements. ${ }^{13}$

Meanwhile, based on the results of the research obtained the self-medication roadmap begins with environmental observations in Cianjur district. In the initial research, interviews were conducted with the results that most people in Cianjur regency had self-medication. After carrying out observations and preliminary research, then proceed with taking research data using a questionnaire addressed to lecturers and education staff in Suryakancana University. After the results of the research are obtained, the data is processed and presented in table form. Furthermore, an analysis of these results is carried out. Many respondents obtained self-medication and there were still respondents who were not precise in the indication and dosage of the drug. The last intervention was carried out to anticipate the occurrence of improper medication by providing direct understanding of the respondents. So that respondents can channel their understanding to the surrounding community.

Figure 2 Self-medication Roadmap
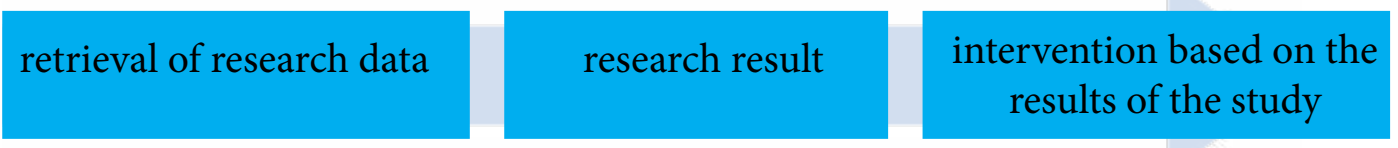

Based on figure 2 above, lecturers and education staff get information about selfmedication right, namely by:

a. Medicines that can be consumed without a doctor's prescription (OTC drugs) by paying attention to the logo listed in the drug packaging;

b. Read the rules of using the drug carefully, including: indications, dosages, side effects and contra indications listed in the drug package;

c. If there is no improvement in the 3 (three) days of the disease, you should immediately contact the doctor to consult;

d. Deliver politely to the stall owner, if around the residence of the respondent there is a shop selling hard drugs.

\section{Word of Mouth Communication (WOMC) as a Cause of Self-medication}

Communication is the process of transferring information from the sender to the receiver, where it can affect individuals or groups in carrying out their consumption activities. Acting as sender is lecturer and education staff while the receiver is the people around him, both on campus, in the family, and in the wider community. The process of finding information from the nearest environment is considered better because this reference source is considered reliable and saves time, the process of getting recommendations from the closest parties about a product can be obtained from referral sources such as friends, family, acquaintances, and professionals. According to Puspitasari, Faturrohman, and Hermansyah ${ }^{14}$ seen from the nature of word of mouth

\footnotetext{
${ }^{13}$ Peraturan Menteri Kesehatan Nomor 924/ Menkes/ Per/ X/1993.

${ }^{14}$ Herni Puspitasari, A Faturrohman, Andi Hermansyah, Do Indonesian community pharmacy workers respond to antibiotics requests appropriately, Tropical Medical International Health, Volume 16, Number 7, July 2011, page 840-6.
} 
communication (WOMC), this communication is needed for the company's internal and external interests. This word of mouth communication is a simple marketing, does not require large costs but the effectiveness is very large. Word of mouth communication is now important in marketing studies, given that communication in word of mouth communication is able to influence consumer purchasing decisions, in this case the decision to choose and purchase drugs for consumption without the need for professional staff. Research on word of mouth communication was 2 (two) times more effective in influencing purchases compared to radio advertising, 4 (four) times compared to personal sales and 7 (seven) times compared to advertisements in magazines and newspapers. According to Krska, and Hansford ${ }^{15}$, consumers trust word of mouth communication more in assessing a product, and influence their purchasing decisions than advertising. The story and experience of someone using a product sounds more interesting and trustworthy which can affect the listener to try the product.

Word of mouth communication is not only done through face to face, but has made use of existing technology, for example by telling something to friends, relatives and family via e-mail as well as websites or social networks such as facebook, twitter, wechat, blackberry messenger, WhatsApp, and other social networks. The story and experience of someone using a product sounds more interesting that can affect the listener to come to try a product. It is proven that word of mouth communication has a strong influence in influencing, persuading and recommending positive things about a product that is promoted to others. Word of mouth communication at the stage of the purchasing process, such as convincing consumers and reducing uncertainty post-purchase. The results of the 2007 Global Consumer Study show that Indonesia is included in the top 5 (five) countries where word of mouth communication is considered the most credible form of advertising. Of the 47 countries in the world, Indonesia is ranked 3 (three), after Hong Kong and Taiwan. In addition, the Indonesian people are unique in terms of attitude, where the Indonesian people have a very strong social level, so the decisionmaking process pays more attention to high togetherness; one example is "manganese from the origin of gathering" is a reflection of culture especially in Java illustrates the strength of group and community formation. The impact of this strong community level is huge for marketing strategies, especially in the context of market penetration. ${ }^{16}$

Understanding self-medication by lecturers and educational staff that has been obtained can be promoted to people or communities around them using word of mouth communication so that campuses and families and communities aware of self-medication are created, self-medication properly. The majority of respondents were highly educated and under 30 years of age, this is the basic capital in word of mouth communication to the general public, not limited to the campus community, the potential of lecturers and education staff to volunteer self-medication right.

\section{CONCLUSION}

Based on the results of the study, it can be concluded that most of the respondents did self-medication and there were still respondents who did self-medication not according to the drug, the dose, or did not understand the existence of contra-indications and side

\footnotetext{
${ }^{15}$ John Krska and D. Hansford, Are customers requesting medicines by name less likely to be advised or referred? Provision of over-the-counter H2-receptor antagonists and alginate products from pharmacies, International Journal of Pharmacy Practice, Volume 11, Number 2, December 2013, page 33-9.

16 Marlina Kurnia, Rochiyati Murniningsih dan Agung Dhany Prasetyo, Pengaruh Word Of Mouth Communication Terhadap Keputusan Konsumen UMKM Di Area Wisata Kuliner Badaan Kota Magelang, Jurnal Fakultas Ekonomi Universitas Muhammadiyah Magelang, Volume 4, Nomor 2, Desember 2015, page 12-25.
} 
effects of drugs and there were still polypharmacy. After delivering an understanding of correct self-medication, respondents understand and are expected to be transmitted to the surrounding through various media with word of mouth communication.

\section{REFERENCES}

\section{Book}

F. Tengker, 2010, Hukum Kesehatan Kini dan Disini, Mandar Maju, Bandung.

\section{Journal}

Aris Widayati, Health Seeking Behavior di Kalangan Masyarakat Urban Di Kota Yogyakarta, Jurnal Farmasi Sains Dan Komunitas, Volume 9, Nomor 2, November 2012.

Cristian Brata and Benny Marjadi, Information-gathering for self-medication via eastern Indonesian community pharmacies: a cross-sectional study, BMC Health Services Research. Volume 30, Number 2, December 2015.

Ferdinand Smith, Community pharmacy in Ghana: enhancing the contribution to primary health care, Health Policy Planning, Volume 19, Number 4, April 2004.

Herni Puspitasari, A Faturrohman, Andi Hermansyah, Do Indonesian community pharmacy workers respond to antibiotics requests appropriately, Tropical Medical International Health, Volume 16, Number 7, July 2011.

Herika Jennifer dan Endah Saptutyningsih, Preferensi Individu Terhadap Pengobatan Tradisional Di Indonesia, Jurnal Ekonomi dan Studi Pembangunan, Volume 16, Nomor 1, April 2015.

HS. Krishnan and M. Schaefer, Evaluation of the impact of pharmacist's advice giving on the outcomes of self-medication in patients suffering from dyspepsia, Pharmacy World Science, Volume 22, Number 3, September 2010.

John Krska and D. Hansford, Are customers requesting medicines by name less likely to be advised or referred? Provision of over-the-counter H2-receptor antagonists and alginate products from pharmacies, International Journal of Pharmacy Practice, Volume 11, Number 2, December 2013.

Marlina Kurnia, Rochiyati Murniningsih dan Agung Dhany Prasetyo, Pengaruh Word Of Mouth Communication Terhadap Keputusan Konsumen UMKM Di Area Wisata Kuliner Badaan Kota Magelang, Jurnal Fakultas Ekonomi Universitas Muhammadiyah Magelang, Volume 4, Nomor 2, Desember 2015.

MJ Herman and AL Susyanty, An analysis of pharmacy services by pharmacist in community pharmacy, Buletin Penelitian Sistem Kesehatan, Volume 15, Number 3, March 2012.

Muhammad Hakim, Indeks Pembangunan Manusia Indonesia, Jurnal Ekonomia, Volume 6, Nomor 2, Desember 2013.

NM. Agabna, Self-medication, Sudan Journal of Rational Use of Medicine, Volume 5, Nomor 6, June 2014.

SI Bello and IK Bello, Community pharmacist impacts on self-medication management among ruraldwellers, Kwara state central, Nigeria, International Journal Research Development Pharmacy Law Science, Volume 2, Number 5, May 2013. 
Susi Ari Kristina, Yayi Suryo Prabandari dan Riswaka Sudjaswadi, Perilaku Pengobatan Sendiri yang Rasional pada Masyarakat Kecamatan Depok dan Cangkringan Kabupaten Sleman, Majalah Farmasi Indonesia, Volume 19, Nomor 1, June 2008.

Supardi Sudibyo dan Mulyono Notosiswoyo, Pengobatan Sendiri Sakit Kepala, Demam, Batuk Dan Pilek Pada Masyarakat Di Desa Ciwalen, Kecamatan Warungkondang, Kabupaten Cianjur, Jawa Barat, Majalah Ilmu Kefarmasian, Volume II, Nomor 3, September 2016.

Yin Fang and K Zhang, Pharmacists' perception of pharmaceutical care in community pharmacy: a questionnaire survey in Northwest China, Health Social Care Community, Volume 19, Number 2, December 2011.

\section{Thesis}

Thang, DX., 2013, An investigation of non-prescription medicine supply in community pharmacies in Hanoi Vietnam, PhD Thesis, University of Nottingham, Nottingham UK.

\section{Law Regulation}

Human Development Report 2016 (Human Development for Everyone), United Nation Development Program (UNDP).

Peraturan Presiden Republik Indonesia Nomor 10 Tahun 2016 Tentang Dosen Dan Tenaga Kependidikan Pada Perguruan Tinggi Negeri Baru.

Peraturan Menteri Kesehatan Nomor 919/ Menkes/ Per/ X/1993.

Peraturan Menteri Kesehatan Nomor 924/ Menkes/ Per/ X/1993.

Rencana Strategi Kementerian Kesehatan 2015-2019.

Statistik BPS Provinsi Jawa Barat No. 38/07/32/Th.XVIII, 1 Juli 2016 